\title{
NEW BOOK ON THE KARST OF EASTERN SERBIA - THE KARST OF JOVAN CVIJIĆ
}

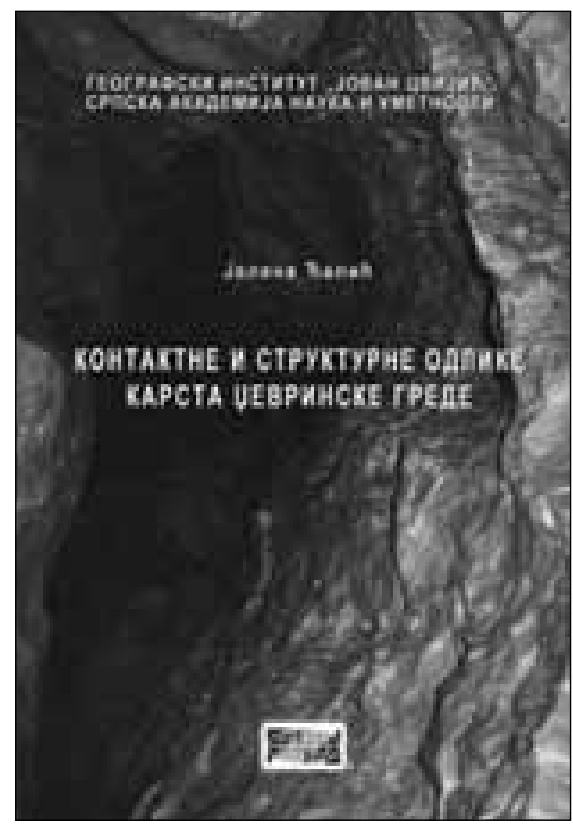

After several years of research the young member of "Jovan Cvijić" Institute and a doctoral student of Karstology, Jelena Ćalić published her master work: Kontaktne i strukturne odlike karsta Dževrinske grede (Karst of the Ridge Dževrinska Greda - Contact Features and Structural Characteristics), the number 72 of the Special Issues of the Geographical Institute "Jovan Cvijićc, Serbian Academy of Sciences and Arts, 163 pp, Belgrade 2008, ISBN: 978-86-80029-41-2, 24 x 17 cm, paperback, 83 figures, 8 tables. The book is published in Serbian (cyrillics), but with relatively detailed English summary and figure captions in English too.

This regional karstological study is actually a published version of the author's M.Sc thesis, defended back in 2003 at the Faculty of Geography in Belgrade. The studied karst area, Dževrinska Greda, is situated in Southern Carpathians in Eastern Serbia. It is a N-S oriented limestone ridge, extending further to the north to Romania, across the Danube River. Thanks to its length of $18 \mathrm{~km}$, and average width of only $250 \mathrm{~m}$, Dževrinska Greda hosts a variety of features related to contact karst and fluviokarst. Position along a regional structural dislocation, the Dževrin fault, implies significant structural impacts on karst development.
Apart from Introduction and Conclusion, the book consists of five major chapters. The chapter on theoretical bases of contact karst includes the overview of selected prominent references published on that subject, including the definition of stripe karst, given by S.E. Lauritzen in Acta Carsologica in 2001. According to that definition, the karst of Dževrinska Greda can be categorized as an example of stripe karst.

The chapter on basic geological and geomorphological characteristics of the study area comprises the interpretation of regional lithological and structural settings, as well as the geological circumstances in which the limestones of Dževrinska Greda have been tectonically uplifted to the surface. The correspondent geological formations in Romanian Southern Carpathians are mentioned as well. General geomorphological overview of the study area is given as an introduction to the next chapter - detailed interpretations of surface and underground forms of karst morphology, for each of the five defined topographical sub-units.

A particular chapter is dedicated to the Dževrin fault - its kinematics and impact on karst development. Initially, this was a normal fault that uplifted the limestone ridge to the surface, while presently its movement is dextral transcurrent. Stress axes for both types of movements have been calculated. More than 600 field measurements of fracture orientations have been statistically processed and interpreted. The chapter on hydrological characteristics includes the data on discharge, physical and chemical characteristics of waters of several ponors and springs, as well as discussion on water balance and groundwater flow directions.

The book is a good example of serious work on karst of young Serbian researchers deserving the name of their institute as well as the name of one of the founders of modern Karstology, Jovan Cvijić. For a free copy, please contact the author at $<$ j.calic@sezampro.rs $>$. The full.pdf version of the book is available at the web page of the Geographical Institute "Jovan Cvijić": www.gi.sanu.ac.rs

Andrej Kranjc 